\title{
Effect of Monitoring Techniques on Project Performance of Kenyan State Corporations
}

\author{
Muchelule Yusuf Wanjala \\ Prof. Mike Amuhaya Iravo \\ Prof. Romanus Odhiambo \\ Dr. Noor Ismail Shalle
}

Jomo Kenyatta University of Agriculture and Technology, Kenya

doi: 10.19044/esj.2017.v13n19p264 URL:http://dx.doi.org/10.19044/esj.2017.v13n19p264

\begin{abstract}
Monitoring practices are the continuous routine in the tracking of key elements of project implementation performance that is: inputs (resources, equipment) activities and outputs, through recordkeeping and regular reporting through assessment of an on-going or completed project to determine its actual impact against the planned impact in relation to its design, implementation, and results. However, monitoring practices implementation has been a challenge over years, organizations have crumbled due to failure to master monitoring best practices in the performance of their projects. The main objective of this study is to investigate the influence of monitoring techniques on project performance of Kenyan State Corporations. Simple random sampling was used to select 65 state corporations which form the sample size. Data were collected from the sample size using questionnaires with both open and closed questions. The data were analyzed using descriptive and inferential statistics as well as qualitative methods. The relationships between variables were determined using person correlation and t-test. Assessments of normality were done by Shapiro-Wilk test. Findings showed that Monitoring techniques $(\beta 3=0.674$, $\mathrm{p}<0.05$ ) has significant affect project performance.
\end{abstract}

Keywords: Project appraisals, project completion, project cost analysis, project mapping, project variances

\section{INTRODUCTION}

Monitoring is the continuous assessment of project implementation about design schedules on inputs, infrastructure, and services by project beneficiaries. Simon further observes that project monitoring is periodic of a project's relevance, performance, efficiency, and impact both expected 
and unexpected about stated objectives.In 1960's the approach of earned value management development whose aim is to monitor project progress based on scope, time, cost and quality. According to most literature monitoring provide information to make decisions regarding project activities require diverse types of monitoring (Shapiro 2011). However, the most in monitoring with project practitioners were developed on monitoring Matrix, basing on Logical Framework Approach to monitoring (Pinto, 2007).

Ling (2004) reported that no conflict exists between performance and results indicators; while effective monitoring track both unifying principles apply to ensure their synchronicity either. A project that is diligently monitored and evaluated for financial oversight and compliance with sound management and performance principles may very well achieve no impacts. The emphasis on aid effectiveness and results-based development obliges practitioners empirically to demonstrate the impacts of their projects and programs. In 2005, the Ministry of Planning and National Development commissioned work on the design of an appropriate framework for Monitoring in the National Development Programme as a collective effort by the Government, Private Sector, and Civil Societies, Republic of Kenya implementation of monitoring and evaluation (2005).

This proposed monitoring framework has not been fully operational to track projects performance of development projects had not gone unnoticed in Kenya with the context in which the National Integrated Monitoring System (NIMES) was established in 2003/2004 and adjusted in 2007/2008 when Kenya's Vision 2030 and its five-year Medium Term Plan replaced Economic Recovery Strategy.Monitoring, therefore, is a practice that is useful and relevant for the actors in the development world (Asare, 2010). However, many mainstream Monitoring practices tend to be isolated and disconnected from management and decision-making. Many programs and projects are driven by pre-set targets and actions, such that is an additional burden on application teams, and their monitoring practice is limited to the fulfillment of reporting requirements of governments (Steff, 2008).

Organizations are currently in the process of reviewing ways in which monitoring can achieve greater consistency and effectiveness (World Bank, 2008), that is, where monitoring will enable them to judge the impact of a performance as well as obtain recommendations on how future interventions can be improved (UNDP, 2009). However, one shortcoming of monitoring practices is that there are no set standards for measuring its quality (Chaplowe, 2008). It is, therefore, subjective and relies on the rule of thumb. Although monitoring is used mainly for checking projects impact as 
well as establish whether it meets its goals and objectives, they are also a mandatory requirement for government sponsored projects where governments use them to determine efficient use of their funds by organizations.

The ability to measure and demonstrate outcomes and impacts relies on the use of indicators that are reliable data, and on the capacity to systematically collect and analyze that information. In Kenya, state corporations are the useful engine of economic growth and recovery through the provision of public services (Njiru,2008).However, poor service delivery - due to corruption, fraud, nepotism and gross mismanagement- in state corporations has increased the country's cost of production thereby adversely affecting Kenya's external competitiveness and leading to loss of jobs and of economic opportunities (RoK, 2005). The main aim of this study was to determine the effect of Monitoring techniques on project performance in state Corporations in Kenya.

\section{LITERATURE REVIEW}

The effectiveness of project monitoring is also dependent on the techniques practices used. Various monitoring techniques have been singled out for the literature review. Stem et al. (2005) established that some of the monitoring techniques that may have been applied by project managers and monitoring teams include: basic research; accounting and certification; status assessment; and effectiveness measurement. Alotaibi(2011) in his study discovered that Saudi Arabia lacked an appropriate construction contractor performance monitoring framework, and the identification and exploration criteria and sub-criteria for a selection framework. Lack of monitoring framework has a negative effect on the project success.

Mladenovic et' al (2013) also established a two layers technique for the assessment of Private-Public Partnership projects. The first stage is based on a monitoring of ultimate project objectives from the standpoint of each stakeholder, i.e. profitability for the private sector, effectiveness and value for money for the public sector, and level of service for users. The Balanced Scorecard is another technique that evaluates projects. Balanced scorecard evaluates projects by four perspectives which are, the financial perspective, customer perspective, Internal Business Process, and Learning \&Growth.

Participatory monitoring is one of the techniques used in the monitoring of performance. The World Bank (2012) defines participatory monitoring as the technique that involves stakeholders such as the project beneficiaries, staff, and government and community in the design and implementation of the project monitoring as opposed to the conventional technique. Ideally, all the stakeholders in the participatory monitoring are involved in identifying the project, the objectives and goals, and 
identification of the indicators that were used in monitoring. The stakeholders are also involved in collection and analysis of the data and capturing the lessons. The role of the managers of the project is to facilitate the monitoring process. Other techniques include stochastic methods, Fuzzy logic model, and miscellaneous methods. Of all the methods, the Earned Value Analysis (EVA) has remarkable advantages in accuracy, flexibility, and adaptability for project complexity. This may have contributed to Malaysian government deciding to implement EVA to enhance the level of project management for the whole country (Abdul-Rahman, Wang, \& Muhammad, 2011).

In many instances, participatory strategies are more cost-effective than projects based on so-called blueprint techniques, so monitoring for costeffectiveness would promote participation in these cases. monitoring for cost-effectiveness does not assume, however, that participatory techniques are right for all projects. The empowerment of project beneficiaries is interesting from an analytic viewpoint because it can be seen both as a means to improving project designs and as an end in itself. For this reason, monitoring for cost-effectiveness views empowerment in a dual light. As a means, monitoring for cost-effectiveness considers empowerment like any other possible ways to be considered in program design. As an end, monitoring for cost-effectiveness considers successful empowerment to be a benefit which must be valued and counted along with other benefits in the assessment of a project's cost-effectiveness.

Under monitoring for cost-effectiveness, both more and less participatory projects are considered within the same monitoring framework. Other techniques used in monitoring are the frameworks. This includes the theory based and logical framework. Theory-based monitoring allows an indepth understanding of the workings of a program or project. In particular, it need not assume simple linear cause-and-effect relationships (Davidson, 2000). It applies a systems technique where the success of the intervention is affected by other factors in the environment which should be identified and how they might interact, it can then be decided which steps should be monitored as the program develops, to see how well they are in fact borne out. Moreover, where the data show these factors have not been achieved, a reasonable conclusion is that the program is less likely to be successful in achieving its objectives (Uitto, 2004).A précis of literature regarding techniques to monitoring in project management includes basic research, accounting, and certification, status assessment, effectiveness measurement, Objectives monitoring - value for money, Balanced Scorecard and Earned Value Analysis. 


\section{METHODOLOGY Research Design}

A research design provides a framework for the collection and analysis of data (Bryman \& Bell, 2011). It contains the blueprint for the collection, measurement, and analysis of data (Kothari, 2004). There are many research designs which can be classified into an exploratory, descriptive, correlational or causal but their distinctions are not absolute (Churchill \& Iacobucc, 2005). The research study, therefore, used descriptive research designs. Descriptive research is typically guided by hypothesis and focuses on the frequency with which something occurs or the relationship between variables (Churchill \& Iacobucc, 2005). The descriptive research helped probe specific aspects of study variables by collecting the information of a set of parameters known beforehand that were desirable to collect data about (Churchill \& Iacobucc, 2005).

\section{Target population}

The target population of this study was 187 state corporations in Kenya, which include the commercial state corporation, executive agencies, independent regulatory agencies, research institutions, public universities, tertiary education and training institutions (RoK, 2013). The choice of the state corporations is justified by the fact that monitoring practices issues are becoming a major concern with the government fighting hard to ensure that there is value for money on services performed. The target respondents will include project managers, finance officers, project team leaders and two enduser key stakeholders who are going to be area leaders affected by the project. The target population of the study is highlighted as follows 1

Table 1:

State Corporations in Kenya

\begin{tabular}{lll}
\hline S/No. & Categories of State Corporations & Number of Entities \\
\hline 1 & Commercial state corporations & 34 \\
2 & Commercial state corporations with strategic function & 21 \\
3 & Executive agencies & 62 \\
4 & Independent regulatory agencies & 25 \\
5 & Research institutions, public universities \& tertiary & 45 \\
& education & $\mathbf{1 8 7}$ \\
Total inventory of State Corporations as of October 2013
\end{tabular}

Source: (RoK, 2013)

\section{Sampling Technique}

Sampling refers to the selection of a few items that are as representative as possible to produce a miniature cross-section of all items constituting a population in a field of inquiry. A survey so conducted is known as a sample survey (Kothari, 2004). A sample is the segment of the population that is selected for investigation. It is a subset of the population 
(Bryman \& Bell, 2011). Sample size refers to the number of items to be selected from the population to constitute a sample. A sampling design is a definite plan of how a sample should be selected from a given population and what size such a sample should be while the sampling technique refers to the process so conducted to provide a basis of generalizing results about the population (Kothari, 2004).

The sampling technique that was used in the study is simple random sampling. With simple random sampling, each unit of the population has an equal probability of inclusion in the sample (Bryman \& Bell, 2011). The sample size (n) can be adjusted using the Yamane formula (1967). In this formula, sample size can be calculated at 3\%, 5\%, 7\% and 10\% precision (e) levels. Confidence level used is $95 \%$ with degree of variability (p) equivalent to $50 \%(0.5)$.

$$
\begin{aligned}
& \mathrm{n}=\frac{N}{1+N e^{2}} \mathrm{n}=\text { sample size } \\
& \mathrm{N}=\text { target population }(187) \\
& \mathrm{e}=\text { margin error of } 10 \%
\end{aligned}
$$

In the proposed study, the sample size were calculated at precision level of $10 \%(\mathrm{e}=0.1)$.

Sample size in this study is

$$
\begin{gathered}
\mathrm{n}=\frac{187}{1+\left(187 \times 0.1^{2}\right)} \\
\mathrm{n}=\frac{187}{2.87} \\
\mathrm{n}=65
\end{gathered}
$$

\begin{tabular}{|c|c|c|c|}
\hline Categories of State Corporations & $\begin{array}{l}\text { Number of } \\
\text { Entities }\end{array}$ & $\begin{array}{l}\text { the sample } \\
\text { for entities }\end{array}$ & $\begin{array}{l}\text { the sample for } \mathrm{TM} \\
\text { (6 per firm) }\end{array}$ \\
\hline Commercial state corporations & 34 & 12 & 72 \\
\hline $\begin{array}{l}\text { Commercial state corporations with } \\
\text { strategic function }\end{array}$ & 21 & 7 & 42 \\
\hline Executive agencies & 62 & 22 & 132 \\
\hline Independent regulatory agencies & 25 & 9 & 54 \\
\hline $\begin{array}{l}\text { Research institutions, public } \\
\text { universities \& tertiary education } \\
\text { Total inventory of State Corporations } \\
\text { as of October }\end{array}$ & 45 & 16 & 96 \\
\hline Total & 187 & 65 & 396 \\
\hline
\end{tabular}

Therefore the sample size was 65 state corporations.

Table 2: Sample size

\section{Data Collection Instrument}

The data were taken from reliable sources to ensure the reliability of the study. The research will utilize secondary data collected from Kenya national bureau of statistics, state corporations databases for the period of 
2005 to 2015. Dawson (2009) explains secondary research data involves collecting data using information from studies other researchers have done in the area of the subject. Primary data was collected through questionnaires using a nominal scale. Most of the questions were structured on an agreement continuum using a 5-point Likert-type scale. According to Kothari (2004) questionnaire's is a document that consists of a number of questions in a definite order. The questionnaire was chosen by the researcher because of the importance of reaching a particular person as a respondent. Because each person responds to the same set of questions, the questionnaire will provide an efficient way of collecting responses from a large sample prior to quantitative analysis (Saunders, 2009).

\section{Validity and Reliability of data collection instruments}

Validity is the ability of an instrument to measure what it is designed to measure. It is the correctness or credibility of a description, conclusion, explanation, interpretation, or other sorts of account (Kumar, 2005). According to Kumar (2005), there are two approaches to establishing the validity of a research instrument: logic and statistical evidence. Validity was established by a logical link between questions and the objectives (Kumar, 2005). To begin with, the phrasing of questions were kept in line with the concept of Zikmund (2010) to increase the validity of the study regarding face validity, content validity and construct validity. Face validity is a subjective means of determining whether the instrument is measuring what it is developed to measure while content validity refers to the representativeness of the items on an instrument as related to the entire domain. Construct validity is the ability of indicators and scales to measure accurately the concept under study (Hair, Black, Babin, \& Anderson, 2010).

Reliability is an assessment of the degree of consistency between multiple measurements of a variable (Hair, Black, Babin, \& Anderson, 2010). Reliability is a measure of the degree to which a research instrument yields consistent results or data after repeated trials (Mugenda \& Mugenda, 2003). Reliability relates to the consistency of the data collected and degree of accuracy in the measurements made using a research instrument. The greater the ability of the instrument to produce consistent results, again and again, or rather the repeatability of the measure, the greater is it's reliability. An item analysis was conducted to determine internal consistency and reliability of each individual item as well as each sub-scale of the data collection instrument in accordance with Kumar (2005).

Cronbach's Alpha reliability coefficient, $\alpha$, was used for the internal reliability test. The coefficient normally ranges between 0 and 1 although actually, no lower limits exist. The closer $\alpha$ is to 1.0 the greater the internal consistency of the items in the scale. The size of $\alpha$ was determined by both 
the number of items in the scale and the mean inter-item correlations based upon the formula:

$\alpha=\frac{r k}{[1+(k-1) / r]}$

where;

$\mathrm{k}=$ is the number of items considered and $\mathrm{r}=$ is the mean of inter-item correlations.

George \& Mallery (2003) provide the following commonly accepted rules of thumb: $\alpha \geq 0.9-$ Excellent; $0.9>\alpha \geq 0.8-$ Good; $0.8>\alpha \geq 0.7-$ Acceptable; $0.7>\alpha \geq 0.6$ - Questionable; $0.6>\alpha \geq 0.5-$ Poor and $0.5>\alpha-$ Unacceptable. Therefore, ideally, the Cronbach Alpha coefficient of a scale should be at least acceptable, that is, above 0.7 . The reliability results of the study are illustrated in Table 3

Table 3: Reliability Analysis for Monitoring Tool

\begin{tabular}{|c|c|c|c|}
\hline & $\begin{array}{l}\text { Corrected } \\
\text { Item-Total } \\
\text { Correlation } \\
\end{array}$ & $\begin{array}{l}\text { Squared } \\
\text { Multiple } \\
\text { Correlation }\end{array}$ & $\begin{array}{l}\text { Cronbach's } \\
\text { Alpha if Item } \\
\text { Deleted }\end{array}$ \\
\hline $\begin{array}{l}\text { Monitoring tools are well assessed if } \\
\text { they are applicable in organization } \\
\text { activities }\end{array}$ & 0.601 & 0.893 & 0.781 \\
\hline Employees are well trained on & & & \\
\hline $\begin{array}{l}\text { Monitoring tools in organization } \\
\text { projects }\end{array}$ & 0.516 & 0.661 & 0.794 \\
\hline $\begin{array}{l}\text { The organization consult widely on } \\
\text { the best monitoring tools to be used } \\
\text { The organization use monitoring tools }\end{array}$ & 0.253 & 0.702 & 0.833 \\
\hline $\begin{array}{l}\text { which are internationally recognized } \\
\text { The organization audits its financial }\end{array}$ & 0.375 & 0.857 & 0.818 \\
\hline $\begin{array}{l}\text { tools in controlling its project cost } \\
\text { Metrics are used to check risks in }\end{array}$ & 0.756 & 0.813 & 0.749 \\
\hline organization & 0.79 & 0.899 & 0.74 \\
\hline $\begin{array}{l}\text { Inspection checklist is used in } \\
\text { standardizing organization monitoring } \\
\text { practices }\end{array}$ & 0.578 & 0.877 & 0.783 \\
\hline Cronbach's Alpha & 0.813 & & \\
\hline Cronbach's Alpha Based on & & & \\
\hline Standardized Items & 0.807 & & \\
\hline
\end{tabular}

As evidenced in Table 3, all the monitoring tools items had a Cronbach value of over .7. Cronbach alpha value of 0.70 or higher indicates that the gathered data are reliable as they have a relatively high internal consistency and can be generalized to reflect opinions of all respondents in the target population about monitoring techniques. 


\section{RESULTS AND DISCUSSION Project monitoring techniques}

Based on the findings, variances are conducted on performance, schedule and cost of project activities (mean $=4.42, \mathrm{SD}=0.8$ ). Consequently, project managers can track the difference between the original project plan and what is actually happening in the state corporations. Precisely, a comparison is made between the budget amount and the actual amount spent to quantify how well or bad a project is progressing. Furthermore, there is a proper technique on forecasting project activities (mean $=4.38, \mathrm{SD}=0.97$ ). The implication is that project managers can choose the kind of projects to pursue and evaluate the potential of the ongoing projects. As well, project managers have insight on whether to create new project activities or continue with the existing projects.

Besides, change request have been well handled and documented in the organization (mean $=4.16, \mathrm{SD}=1.14$ ). There is, therefore, a reference point on what needs to be accomplished with regard to the plans and what needs to be done to accomplish the said plans. As well, project mapping is conducted in projects activities (mean $=4.15$, SD $=0.73$ ). Moreover, participatory monitoring and approach are used to determine performance (mean $=3.98, \mathrm{SD}=0.77$ ). As such, key stakeholders are engaged in reflecting and tracking the progress of their project and in particular the attainment of the set goals/objectives. Also, stochastic method is used in monitoring practices (mean $=3.98, \mathrm{SD}=1.06$ ). In addition, the organization conducts monthly project appraisals (mean $=3.97, \mathrm{SD}=0.71$ ). The implication is that the state corporations are able to assess in a structured way the case for proceeding with a given project activity and its overall viability. Generally, the findings on monitoring techniques summed up to a mean of 3.98, standard deviation 0.98 and kurtosis 2.66 . 
Table 4: Monitoring techniques

\begin{tabular}{|c|c|c|c|c|c|c|c|c|c|}
\hline & & sd & d & Ns & $\mathrm{a}$ & so & Mean & $\begin{array}{l}\text { Std. } \\
\text { Deviation }\end{array}$ & Kurtosis \\
\hline $\begin{array}{l}\text { The organization conducts monthly } \\
\text { projects appraisals }\end{array}$ & $\begin{array}{l}\text { Freq. } \\
\%\end{array}$ & $\begin{array}{l}0 \\
0\end{array}$ & $\begin{array}{l}23 \\
6.7\end{array}$ & $\begin{array}{l}22 \\
6.4\end{array}$ & $\begin{array}{l}241 \\
70.1\end{array}$ & $\begin{array}{l}58 \\
16.9\end{array}$ & 3.97 & 0.71 & 2.08 \\
\hline $\begin{array}{l}\text { There is a proper technique on } \\
\text { forecasting project activities }\end{array}$ & $\begin{array}{l}\text { Freq. } \\
\%\end{array}$ & $\begin{array}{l}0 \\
0\end{array}$ & $\begin{array}{l}23 \\
6.7\end{array}$ & $\begin{array}{l}52 \\
15.1\end{array}$ & $\begin{array}{l}41 \\
11.9\end{array}$ & $\begin{array}{l}228 \\
66.3\end{array}$ & 4.38 & 0.97 & 0.18 \\
\hline $\begin{array}{l}\text { Variances are conducted on } \\
\text { performance, schedule and cost of } \\
\text { project activities }\end{array}$ & $\begin{array}{l}\text { Freq. } \\
\%\end{array}$ & $\begin{array}{l}0 \\
0\end{array}$ & $\begin{array}{l}23 \\
6.7\end{array}$ & $\begin{array}{l}0 \\
0\end{array}$ & $\begin{array}{l}130 \\
37.8\end{array}$ & $\begin{array}{l}191 \\
55.5\end{array}$ & 4.42 & 0.8 & 2.76 \\
\hline $\begin{array}{l}\text { A change request has been well } \\
\text { handled and documented in the } \\
\text { organization. }\end{array}$ & $\begin{array}{l}\text { Freq. } \\
\%\end{array}$ & $\begin{array}{l}23 \\
6.7\end{array}$ & $\begin{array}{l}61 \\
17.7\end{array}$ & $\begin{array}{l}76 \\
22.1\end{array}$ & $\begin{array}{l}184 \\
53.5\end{array}$ & $\begin{array}{l}0 \\
0\end{array}$ & 4.16 & 1.14 & 1.39 \\
\hline $\begin{array}{l}\text { Participatory monitoring and } \\
\text { approach are used to determine } \\
\text { performance. }\end{array}$ & $\begin{array}{l}\text { Freq. } \\
\%\end{array}$ & $\begin{array}{l}0 \\
0\end{array}$ & $\begin{array}{l}23 \\
6.7\end{array}$ & $\begin{array}{l}37 \\
10.8\end{array}$ & $\begin{array}{l}208 \\
60.5\end{array}$ & $\begin{array}{l}76 \\
22.1\end{array}$ & 3.98 & 0.77 & 0.88 \\
\hline $\begin{array}{l}\text { Stochastic method is used in } \\
\text { monitoring practices }\end{array}$ & $\begin{array}{l}\text { Freq. } \\
\%\end{array}$ & $\begin{array}{l}0 \\
0\end{array}$ & $\begin{array}{l}59 \\
17.2\end{array}$ & $\begin{array}{l}19 \\
5.5\end{array}$ & $\begin{array}{l}136 \\
39.5\end{array}$ & $\begin{array}{l}130 \\
37.8\end{array}$ & 3.98 & 1.06 & -0.5 \\
\hline $\begin{array}{l}\text { Project mapping is conducted in } \\
\text { projects activities } \\
\text { monitoring techniques }\end{array}$ & $\begin{array}{l}\text { Freq. } \\
\%\end{array}$ & $\begin{array}{l}0 \\
0\end{array}$ & $\begin{array}{l}23 \\
6.7\end{array}$ & $\begin{array}{l}225 \\
65.4\end{array}$ & $\begin{array}{l}96 \\
27.9\end{array}$ & $\begin{array}{l}0 \\
0\end{array}$ & 3.98 & 0.98 & $\begin{array}{l}2.73 \\
2.66\end{array}$ \\
\hline
\end{tabular}

\section{Project performance}

From Table 5, there was doubt whether most of the projects initiated are of good quality (mean $=3.42, \mathrm{SD}=1.27$ ). It is also uncertain if projects are implemented and completed within expected timeframe and budget (mean $=2.8, \mathrm{SD}=1.45$ ). Similarly, it is undefined if concluded projects normally meet the required scope and quality projects standard (mean $=2.61$, $\mathrm{SD}=1.41$ ). Furthermore, there is uncertainty as to whether there is proper utilization of project resources on its performance (mean $=2.5, \mathrm{SD}=$ 1.54).The poor acquisition of the suitable monitoring practices by state corporations' is as a result of the emphasis on physical infrastructure such as computers than on conceptual training.

On the same note, there is doubt if the project meets its intended goals and objectives (mean $=2.47, \mathrm{SD}=1.72$ ). The implication is that the concerned stakeholders lack sufficient data and metrics to ascertain that the projects have met their intended goals and objectives. However, the respondents denied that monitoring facilitates transparency and accountability of the project resources (mean $=2.29, \mathrm{SD}=1.13$ ). It could be that there is resource misuse despite concerted efforts at monitoring the projects. The respondents also denied that the organization gives regular 
project progress reports on its performance (mean $=2.1, \mathrm{SD}=1.31$ ). On the whole, findings on project performance summed up to a mean of 3.64, standard deviation 0.93 and kurtosis -0.6 .

Table 5: Project performance

\begin{tabular}{|c|c|c|c|c|c|c|c|c|c|}
\hline & & SD & $\mathrm{D}$ & NS & A & SA & Mean & $\begin{array}{l}\text { Std. } \\
\text { Deviation }\end{array}$ & Kurtosis \\
\hline $\begin{array}{l}\text { The project meet its intended goals } \\
\text { and objectives }\end{array}$ & $\begin{array}{l}\text { Freq. } \\
\%\end{array}$ & $\begin{array}{l}177 \\
51.5\end{array}$ & $\begin{array}{l}19 \\
5.5\end{array}$ & $\begin{array}{l}52 \\
15.1\end{array}$ & $\begin{array}{l}0 \\
0\end{array}$ & $\begin{array}{l}96 \\
27.9\end{array}$ & 2.47 & 1.72 & -1.4 \\
\hline $\begin{array}{l}\text { There is proper utilization of project } \\
\text { resources on its performance. }\end{array}$ & $\begin{array}{l}\text { Freq. } \\
\%\end{array}$ & $\begin{array}{l}132 \\
38.4\end{array}$ & $\begin{array}{l}0 \\
0\end{array}$ & $\begin{array}{l}64 \\
18.6\end{array}$ & $\begin{array}{l}70 \\
20.3\end{array}$ & $\begin{array}{l}78 \\
22.7\end{array}$ & 2.5 & 1.54 & -1.1 \\
\hline $\begin{array}{l}\text { Projects are implemented and } \\
\text { completed within expected } \\
\text { timeframe and budget }\end{array}$ & $\begin{array}{l}\text { Freq. } \\
\%\end{array}$ & $\begin{array}{l}95 \\
27.6\end{array}$ & $\begin{array}{l}82 \\
23.8\end{array}$ & $\begin{array}{l}0 \\
0\end{array}$ & $\begin{array}{l}132 \\
38.4\end{array}$ & $\begin{array}{l}35 \\
10.2\end{array}$ & 2.8 & 1.45 & -1.6 \\
\hline $\begin{array}{l}\text { Concluded projects normally meet } \\
\text { the required scope and quality } \\
\text { projects standard }\end{array}$ & $\begin{array}{l}\text { Freq. } \\
\%\end{array}$ & $\begin{array}{l}95 \\
27.6\end{array}$ & $\begin{array}{l}82 \\
23.8\end{array}$ & $\begin{array}{l}98 \\
28.5\end{array}$ & $\begin{array}{l}0 \\
0\end{array}$ & $\begin{array}{l}69 \\
20.1\end{array}$ & 2.61 & 1.41 & -0.9 \\
\hline $\begin{array}{l}\text { Monitoring facilitates transparency } \\
\text { and accountability of the of project } \\
\text { resources. }\end{array}$ & $\begin{array}{l}\text { Freq. } \\
\%\end{array}$ & $\begin{array}{l}95 \\
27.6\end{array}$ & $\begin{array}{l}125 \\
36.3\end{array}$ & $\begin{array}{l}70 \\
20.3\end{array}$ & $\begin{array}{l}37 \\
10.8\end{array}$ & $\begin{array}{l}17 \\
4.9\end{array}$ & 2.29 & 1.13 & -0.3 \\
\hline $\begin{array}{l}\text { The organization gives regular } \\
\text { project progress reports on its } \\
\text { performance }\end{array}$ & $\begin{array}{l}\text { Freq. } \\
\%\end{array}$ & $\begin{array}{l}156 \\
45.3\end{array}$ & $\begin{array}{l}101 \\
29.4\end{array}$ & $\begin{array}{l}0 \\
0\end{array}$ & $\begin{array}{l}69 \\
20.1\end{array}$ & $\begin{array}{l}18 \\
5.2\end{array}$ & 2.1 & 1.31 & -0.6 \\
\hline $\begin{array}{l}\text { Most of the project initiated are of } \\
\text { good quality }\end{array}$ & $\begin{array}{l}\text { Freq. } \\
\%\end{array}$ & $\begin{array}{l}19 \\
5.5\end{array}$ & $\begin{array}{l}106 \\
30.8\end{array}$ & $\begin{array}{l}0 \\
0\end{array}$ & $\begin{array}{l}149 \\
43.3\end{array}$ & $\begin{array}{l}70 \\
20.3\end{array}$ & 3.42 & 1.27 & -1.3 \\
\hline project performance & & & & & & & 3.64 & 0.93 & -0.6 \\
\hline
\end{tabular}

\section{Factor Analysis for Monitoring technique}

Factor analysis for monitoring technique was conducted to ensure that all of the constructs used are valid and reliable before proceeding for further analysis. The study requested that all loading less than 0.5 be suppressed in the output, hence providing blank spaces for many of the loadings. All monitoring techniques factors notably, there is a proper technique on forecasting project activities, variances are conducted on performance, schedule and cost of project activities, participatory monitoring and approach is used to determine performance, project mapping is conducted in projects activities, the organization conducts monthly projects appraisals, change request has been well handled and documented in organization and stochastic method is used in monitoring practices were retained for further data analysis. Additionally, the first factor accounted for $43.614 \%$ of the total variance and the second factor $80.174 \%$ of the total variance. Sampling adequacy was tested using the Kaiser- Meyer- Olkin Measure (KMO measure) of sampling adequacy. As evidenced in Table 6, KMO was greater than 0.5 , and Bartlett's Test was significant. 


\begin{tabular}{lll}
\hline & 1 & 2 \\
\hline There is a proper technique on forecasting project activities & 0.842 & \\
Variances are conducted on performance, schedule, and cost of project activities & 0.878 & 0.574 \\
Participatory monitoring and approach are used to determine performance. & 0.94 & \\
Project mapping is conducted in projects activities & & 0.695 \\
The organization conducts monthly projects appraisals & & 0.925 \\
A change request has been well handled and documented in the organization. & & 0.87 \\
Stochastic method is used in monitoring practices & & 2.559 \\
Total Variance Explained: Rotation Sums of Squared Loadings & 3.053 & 36.56 \\
Total & 43.614 & 80.174 \\
\% of Variance & 43.614 & \\
Cumulative \% & & \\
Kaiser-Meyer-Olkin Measure of Sampling Adequacy. & 0.741 & 2280.046 \\
Bartlett's Test of Sphericity, Approx. Chi-Square & 21 & \\
Df & & 0.000 \\
Sig.
\end{tabular}

Extraction Method: Principal Component Analysis.

Rotation Method: Varimax with Kaiser Normalization.

\section{Factor analysis on Project Performance}

Factor analysis was conducted in order to make sure that the items belong to the same construct (Wibowo 2008). Table 7 illustrates the factor analysis for project performance. As shown in the table, there were no exceptions, as all variables scored above the threshold of 0.5. The criterion for commonality was fulfilled by project performance items notably, the project meets its intended goals and objective, there is proper utilization of project resources on its performance, projects are implemented and completed within expected timeframe and budget, concluded projects normally meet the required scope and quality projects standard, monitoring facilitates transparency and accountability of the of project resources, the organization gives regular project progress reports on its performance and most of the project initiated are of good quality. Additionally, the first factor accounted for $50.596 \%$ of the total variance and the second factor $85.095 \%$ of the total variance. The KMO Measure is an index for comparing the magnitude of the observed correlation coefficients to the magnitude of the partial correlation coefficients. As shown in Table 7, KMO was greater than 0.5, and Bartlett's Test was significant. 


\begin{tabular}{|c|c|c|}
\hline & 1 & 2 \\
\hline The project meets its intended goals and objectives & 0.933 & \\
\hline There is proper utilization of project resources on its performance. & 0.971 & \\
\hline $\begin{array}{l}\text { Projects are implemented and completed within expected timeframe and } \\
\text { budget. }\end{array}$ & 0.912 & \\
\hline $\begin{array}{l}\text { Concluded projects normally meet the required scope and quality } \\
\text { projects standard }\end{array}$ & 0.721 & 0.598 \\
\hline Monitoring facilitates transparency and accountability of the of project resou & urces. & 0.707 \\
\hline The organization gives regular project progress reports on its performance & & 0.891 \\
\hline Most of the project initiated are of good quality & & 0.793 \\
\hline Rotation Sums of Squared Loadings & & \\
\hline Total & 3.542 & 2.415 \\
\hline$\%$ of Variance & 50.596 & $\begin{array}{l}34.5 \\
85.09\end{array}$ \\
\hline $\begin{array}{l}\text { Cumulative \% } \\
\text { KMO and Bartlett's Test }\end{array}$ & 50.596 & 5 \\
\hline Kaiser-Meyer-Olkin Measure of Sampling Adequacy. & $\begin{array}{l}0.253 \\
5627.55\end{array}$ & \\
\hline Bartlett's Test of Sphericity, Approx. Chi-Square & 5 & \\
\hline Df & 21 & \\
\hline Sig. & 0.000 & \\
\hline
\end{tabular}

Extraction Method: Principal Component Analysis.

Rotation Method: Varimax with Kaiser Normalization.

\section{Normality}

Hair et al. (2010), suggested that both the graphical plots and any statistical tests (Shapiro-Wilk or Kolmogorov-Smirnov test) can be used to assess the actual degree of departure from normality. To identify the shape of the distribution, Kolmogorov-Smirnov was used (Shapiro and Wilk,1965) which were calculated for each variable. The results from these tests revealed (Table 8) that all the variables were not significant, which meets the assumptions of normality.

Table 8: Normality

\begin{tabular}{|c|c|c|c|c|c|c|}
\hline & \multicolumn{3}{|c|}{ Kolmogorov-Smirnova } & \multicolumn{3}{|c|}{ Shapiro-Wilk } \\
\hline & Statistic & df & Sig. & Statistic & df & Sig. \\
\hline monitoring techniques & 0.329 & 344 & 0.094 & 0.685 & 344 & 0.089 \\
\hline Project performance & 0.229 & 344 & 0.125 & 0.824 & 344 & $.200 *$ \\
\hline
\end{tabular}

a Lilliefors Significance Correction

\section{Homoscedasticity}

The test for homoscedasticity for two metric variables is best examined graphically or through the use of a statistical test. The Levene Statistic for equality of variances was used to test for the assumption of homoscedasticity. Table 9 shows that testing at the 0.05 level of significance; 
none of the Levene statistics was significant. The assumption of homoscedasticity was not violated.

Table 9: Homoscedasticity

\begin{tabular}{lllll}
\hline & Levene & & & \\
& Statistic & df1 & df2 & Sig. \\
\hline monitoring techniques & 1.191 & 1 & 632 & 0.275 \\
Project performance & 1.494 & 1 & 632 & 0.222 \\
\hline
\end{tabular}

\section{Multicollinearity}

Multicollinearity means that two or more of the independent variables are highly correlated and this situation can have damaging effects on the results of multiple regressions. High multicollinearity is signaled when inter-correlation among the independents is above 0.9 (Hair et al., 2006 as cited by Saunders et al. 2009), 0.8(Garson, 2013), 0.7 (Sekaran and Bougie, 2010), or when high R-squared and significant $F$ tests of the model occur in combination with non-significant t-tests of coefficients. The VIF values were 1.794 which is less than four meaning that there was no multicollinearity.

\section{Correlation}

The correlation between monitoring techniques and project performance was significant $(\mathrm{r}=0.701, \mathrm{P}<0.01)$. This is In line with the study findings by Alotaibi (2011) which showed that lack of an appropriate construction contractor performance monitoring framework had a negative effect on the project success. Besides, Alhyari et' al (2013) found out that balanced scorecard technique was very efficient in monitoring and measuring the performance of e-government in Jordan as well as evaluating their success. Participatory monitoring is also one of the techniques used for monitoring project performance. The World Bank (2012) defines participatory monitoring as the technique that involves stakeholders such as the project beneficiaries, staff, and government in the design and implementation of the project. Involvement of these stakeholders makes it possible for them to lay out steps to meet the desired results. Furthermore, the Earned Value Analysis (EVA) technique enhances project performance in the sense that it is accurate and flexible (Abdul-Rahman, Wang, \& Muhammad, 2011).

\section{CONCLUSION AND RECOMMENDATION}

Monitoring techniques have a positive and significant influence on the project performance of Kenya State corporations. Forecasting of project activities, project mapping, participatory approach were key monitoring techniques used by the State corporations to attain their project objectives and goals. Precisely, the monitoring techniques are in ensuring that the 
project plans are well handled and the concerned stakeholders are engaged in reflecting and tracking the progress of the said project. In the light of this, the monitoring techniques contribute to project success.

Additionally, monitoring techniques are instrumental in enhancing project success. There is, therefore, need for state corporations to make use of change request to develop reference points on what needs to be accomplished and what needs to be done to accomplish the said plans. The state corporations can also make use of forecasting to determine the type of projects to pursue and assess the potential of the ongoing projects. Log frames can also be used to links the project goals and objectives to the inputs and outputs required to implement the project.This study was primarily limited to 65 state corporations which formed the sample size. Therefore, it may not be appropriate to generalize to the whole population of state corporations in this country or any other country. For this reason, further empirical investigations in different regions and countries are needed. The methodology that has been chosen to achieve the research objectives was limited to questionnaires. As such, future research could build on this study by examining monitoring practices in different sectors and industries in both a qualitative and quantitative way

\section{References:}

1. Asare, O. E., (2010). 'Utilization of the multiple aspects of my IMDP learning to improve upon delays in the implementation of capital projects directly linked to production sustainability of the ObuasiMine'.IMDP Thesis, Graduate School of the Business University of Cape Town.

2. Bryman, A., \& Bell, E. (2011). Business Research Methods (3 ed.). New York, United States: Oxford University Press Inc.

3. Chaplowe, S. G., (2008). Monitoring and evaluation planning module. American Red Cross and Catholic Relief services. Washington, DC and Baltimore, MD.

4. Davidson, E., (2000). Ascertaining causality in the theory-based evaluation, in Program Theory in Evaluation: Challenges and Opportunities. New Directions for Evaluation, edited by Rogers P, Has T, Petrosino A, and Huebner T. Washington: World Bank:17-26.

5. Dawson, C. (2009). Introduction to Research Methods. A practical guide for anyone undertaking a research project. How to books Ltd.3 Newtec place, United Kingdom.

6. Kothari, C. R. (2004). Research Methodology: Methods and Techniques. New Delhi: New Age International Publishers. 
7. Ling, F. Y., (2004). Key determinants of performance of DBB projects in Singapore', Building Research and Information, Vol32(2),128-139.

8. Njiru, E. (2008).The Role of State Corporations in a Developmental State: The Kenyan Experience. A paper presented at the $30^{\text {th }}$ African Association for public Administration and Management annual roundtable conference, Accra Ghana On $6^{\text {th }}-10^{\text {th }}$ October.

9. Pinto, J.K., (2007).Project Management: Achieving Competitive Advantage, Upper Saddle River, NJ: Pearson Education.

10. The Republic of Kenya, (2005).Report of Proceeding and Recommendations of the Induction Programme for Directors of State Corporations. Nairobi:

11. The Republic Of Kenya, (2013), Economic Survey Nairobi Kenya: Government Printers.

12. Saunders, M., Lewis, P., \&Thornhill, A., (2009).Research Methods for Business Students, Financial Times/Prentice Hall, (4th Edition), UK, p. 105-108, 134.

13. Sekaran, U., \&Bougie, R., (2010). Research Methods for Business: A Skill Building Approach (5th ed.). West Sussex, UK: John Wiley \& Sons Ltd.

14. Shapiro, J., (2011). Monitoring and Evaluation. Johannesburg: CIVICUS.

15. Shapiro, S. S., \& Wilk, M. B. (1965). An Analysis of Variance Test for Normality (Complete Samples). Biometrika, 52(3/4), 591-611.

16. Steff, D., (2008).Towards monitoring that makes sense: Action research design of a planning, learning and accountability system for a sustainable agriculture program in Eastern Indonesia. Rhodes University Grahams Town, South Africa.

17. Stem, C., Margoluis, R., Salafsky, N., \& Brown, M. (2005). Monitoring and evaluation in conservation: a review of trends and approaches. Conservation Biology, 19(2), 295-309.

18. Uitto, J. A., (2004).Multi-country cooperation around shared waters: Role of Monitoring and Evaluation. Global environmental change, 14(1): 5-14.

19. United Nations Family Planning, UNDP. (2009): International reporting framework-a research guide. Geneva.

20. World Bank, (2008).Infrastructure Assessment, Finance, Private Sector, and Infrastructure Group, Middle East \& North Africa, December 2008.

21. World Bank, (2012).Monitoring and Evaluation: Some tools, methods, and approaches. The World Bank. Washington, D.C. 
22. Yamane, T., (1967).Statistics: An Introductory Analysis, $2^{\text {nd }}$ edition, New York: Harper and Row 